\title{
Changes in the Concept of "Scientific Literature"
}

By the Editorial Committee, Mental Health Book Review Index

THE CURRENT CONCERN with the fate of scientific writings is not new, but new is the shift in emphasis which has put information, not literature, in the center of attention. We may wonder what has happened to the literature of science. Has it been superseded by the computer? Or have we, in the excitement over acquiring a gigantic robot memory, suffered a lapse of our human memory and lost sight of scientific literature as a cultural possession?

At the dawn of western civilization, literature and science were intimately linked. Literature not only absorbed the thought of its time, but could express insights that foreshadowed a knowledge yet to come. Thus Lucretius' poem, De Rerum Natura, has been acclaimed for showing an amazing foreknowledge of atomic science and electronics. This unity of literature and science lasted as long as a unifying view of the world prevailed. The kinship between the ideas of poets and the poetic response of men of science, still strong in contemporaries like Donne and Kepler, then gave way to a new spirit which severed modern science from literature as an art.

De Quincey was the first to delimit literature clearly as a fine art, excluding from it "all books in which the matter to be communicated is paramount to the manner or form of its communication" and, therefore, excluding "all science whatsoever." Thus the expulsion of science from literature became an explicit part of literary theory. De Quincey was
Ilse Bry, of the Mental Health Book Review Index, and Lois Afflerbach, of the Paul Klapper Library, Queens College, are cochairmen of this committee. The present essay is published also as an editorial in Mental Health Book Review Index, VIII, [Whole no. $13_{1}$ (1963), pp. i-iv.

aware, however, that the common use of the word literature was not as discriminating as he would have it: "Popularly, and amongst the thoughtless, it is held to include everything that is printed in a book," or it was a convenient term for expressing inclusively the total books in a language. In a philosophical sense, he asserted, it would be ludicrous to reckon a pharmacopoeia, the Court Calendar, etc., as part of the literature. ${ }^{1}$

Throughout the remainder of the nineteenth century, dictionaries, in their definitions of literature, reflected the adoption of De Quincey's perceptive distinctions but without retaining his value judgments. By the turn of the century it had become necessary to record another meaning: "the whole body of literary productions or writings upon a given subject, or in reference to a particular science or branch of knowledge." Thus in relation to scientific writings in a given field, literature was now again defined in the single, allinclusive sense which De Quincey had

\footnotetext{
1 Thomas De Quincey, "Letters to a Young Man Whose Education Has Been Neglected" (1823), in The Collected Writings of Thomas De Quincey, edited by David Masson (new and enl. ed.; Edinburgh: Black, 1890), X, 14 and 17; "The Poetry of Pope" (1848), ibid., XI, 53.
} 
branded as popular, thoughtless, and ludicrous.

At this point science paid a heavy price for being cut off from the humanities and social sciences, with their longer vistas and openness to social and intellectual history. The nineteenth-century structure of disciplines, each thought of as having a literature of its own, was frozen into twentieth-century scientific bibliography. This meant that a concept of "scientific literature" which was static, rigid, and aloof, gained acceptance at the very time when science itself became more than ever dynamic, fluid, and exposed to interaction with the social scene.

There had been no such conflict so long as the concern with scientific writings was retrospective, as, for example, in the Royal Society's Catalogue of Scientific Papers, 1800-1900, and in a corresponding French national bibliography. ${ }^{2}$ In that case plans drawn up at mid-century were still useful when the work came to fruition at the fin de siècle. Different problems arose, however, when the International Catalogue of Scientific Literature was launched as an enormous project of international cooperation. It called for "a complete index of current scientific literature" beginning with the year 1901 . The basic subject arrangement corresponded to the then recognized disciplines in the exact sciences. It was also felt "that an author's catalogue could not supply the required information, and that it was essential that scientific workers should be kept fully and quickly informed of all new discoveries by means of complete subject indexes." 3 Neither the implicit assumptions nor the language appear to have changed very much over the past

\footnotetext{
' Joseph Deniker, Bibliographies des travaux scientifiques (sciences mathématiques, physiques et natural les) publiés par les sociétés savantes de la France depuis l'origine jusqu'en 1888, dressés sous les auspices du Ministère de l'instruction publique. ( 2 vols.; Paris : Imprimerie Nationale, 1895-1922.)

International Catalogue of Scientific Literature .. 1901-1914. Published for the International Council by the Royal Society of London. (254 vols.; London : 1902-21.)
}

sixty years in the planning of comprehensive, current, scientific information services.

At the turn of the century, a new era began for certain fields of science, for instance, the atomic sciences, genetics, and psychoanalysis. The International Catalogue of Scientific Literature achieved on a worldwide scale what would now be called the coordination of scientific information. Here we have the ingredients of a scholarly study laid out for us. We might ask, for example, how new discoveries, as now recognized, found their way to other scientific workers; what else besides information was involved in their further development and acceptance; what this monumental index of current scientific literature actually contributed to the advancement of scientific knowledge, and at what price. By raising this last question, we do not mean the cost in terms of money and manpower, although this, too, may be of interest today. Rather, we refer to the retarding and inhibiting influences which can now be traced to the International Catalogue. The undertaking, which commanded the authority and resources of its time, has left its mark on bibliographic and library organization up to the present day.

The Bibliographie der deutschen naturwissenschaftlichen Litteratur, also launched in 1901 to report in brief intervals the German material contributed to the annually published International Catalogue, but otherwise coordinated with it, permits a close view of the intellectual strait jacket sanctioned by international consent. The ingenuity with which works in the then emerging behavioral sciences were pressed into a scheme already obsolete at its inception is especially remarkable, but it is also deceptive. We might not think of looking in a bibliography severely limited to the exact sciences for the third German edition of Eugen Dühring's The Marquis de Sade and His Time; Studies in the History of Culture 
and Morals of the Eighteenth Century. Yet there it is, listed under "Physiology of Reproduction," with a cross reference from "Nervous System." 4

Such examples might be multiplied, but it is more important to stress the principle: an index of the world's current scientific literature can be current only if it is organized within the framework of the contemporaneous trends in scientific thinking and research.

An international convention with the power to reconsider and, if necessary, to revise the regulations and schedules approved for the International Catalogue, was to be held in 1905 , in 1910 , and every tenth year afterwards. This liberal foresight was of no avail. Ostensibly, the project was brought to a halt by the World War. Actually, it was breaking down before that of its own weight. In 1922, a leading American librarian, William Warner Bishop, writing in Science, called the surviving set "a monument to the difficulties of the task of an adequate index to the published work of scientists." 5 Four decades later its greatest value might be in helping us to recognize it as a monument to the dangers of attempting to freeze science and, in particular, to the paradox of building obsolete concepts of scientific literature into a new bibliographic system under the guise of the latest advances in information systems management and engineering.

During the past fifty years the link between science and literature that was broken by the rise of modern science in the seventeenth century has begun to be restored. First, there have been significant changes in literary theory. Among the leading ideas here are that literature and science are inseparable expressions

\footnotetext{
- Bibliographie der deutschen naturwissenschaft lichen Litteratur, hrsg. im Auftrage des Reichsamtes des Innern vom Deutschen Bureau der Internationalen Bibliographie in Berlin. I. Bd. (1901-1902) (Jena : Fischer, 1902), pp. 1258, 1263.

5 "The Record of Science," Science, LVI (1922), 214.
}

of the creative human spirit and that, while the working processes of science are indeed incompatible with literature, mankind becomes conscious of itself through literature which is both science and art. It has also been fully recognized that science has had an all-pervading influence upon literature, which in turn becomes the vehicle through which science affects men's whole lives and their modes of thought, emotion, and action; and that science has directly contributed works of the highest rank to literature. ${ }^{6-9}$

A history of scientific literature, based on criteria of value, was first clearly envisaged in 1930 in the dissertation, Studies in the Literature of Natural Science, by J. M. Drachman. ${ }^{10}$ The idea of such a history has since gained in breadth and depth. The progress made may, however, be concealed behind a disclaimer, as in Grant McColley's Literature and Science; an Anthology from English and American Literature, $1600-1900,{ }^{11}$ or behind titles which still avoid the word literature in the context of science, such as Books That Changed Our Minds, ${ }^{12}$ Books That Changed the World, ${ }^{13}$ or books that shaped western civilization, as Molders of the Modern Mind. ${ }^{14}$

Furthermore, we may consider the di-

\footnotetext{
- Conwy Lloyd Morgan, "Science and Literature," Transactions of the Royal Society of Literature, 2d ser., XXIX (1910), 227-53.

'Rolfe Arnold Scott-James, The Making of Literature; Some Principles of Criticism Examined in the Light of Ancient and Modern Theory (London: Secker, 1928; New York: Holt, 1930), pp. 336-43.

${ }^{8}$ Grant MeColley, ed., Literature and Science; an Anthology from English and American Literature, 1600-1900 (Chicago: Packard, 1940), pp. v and 350.

'Harvey Eagleson, "The Beginning of Modern Literature," Stanford Studies in Language and Literature (1941), pp. 348-60.

${ }^{10}$ Julian Moses Drachman, Studies in the Literature of Natural Science (New York: Macmillan, 1930). Thesis (Ph.D.), Columbia University; also issued without thesis note.

11 Op. cit., p. 4.

${ }^{13}$ Malcolm Cowley and Bernard Smith, eds. Books That Changed Our Minds (New York: Doubleday, Doran, 1939 ; 1940).

${ }^{13}$ Robert Bingham Downs, Books That Changed the World (Chicago: ALA, 1956).

14 Robert Bingham Downs, Molders of the Modern Mind; 111 Books That Shaped Western Civilization (New York: Barnes \& Noble, 1961).
} 
versity of forms of writing and publication as a matrix for scientific literature. The past fifty or a hundred years were rich in developments which, while provoking some reaction in the humanities, have gone almost unnoticed in science; for instance, the Festschrift, the invited lecture, the prize essay, the editorial and letter to the editor, the book review and rebuttal, the selected bibliography, and the monographic series or single book appearing under the editorship of a distinguished scholar or scientist. Not only has little been done to study their place and function in scientific discourse, but they are usually omitted from the major scientific information services, which tend to limit themselves to journals and proceedings, technical reports, and sometimes monographs, the material that lends itself to routine processes. Yet those more elusive forms of scholarly presentation have become sensitive instruments, when put at the disposal of the scientific community. Its members often choose these channels to transmit their germinal ideas, their scientific philosophy and theoretical probings, their standards, judgments, and concerns, their wisdom as elder statesmen, in short, the currents of scientific thought and scholarship which give meaning and direction to the minutiae of research and compensate for the narrowing confines imposed by specialization.

In order to develop a concept of scientific literature for our time, we may have to reinterpret a type of publication which serves only the purpose of providing scientific information. This "scientific journalism" spreads as much scientific knowledge as can be reasonably absorbed and digested through the self-organizing audiences reached by the individual journals; it therefore calls into service a large number of scientists with varying editorial responsibilities who see to it that the dissemination of knowledge remains authentic and stimulating, qualities sometimes diluted or lost in abstracting and index- ing. With the spread of scientific literacy, the number of authors and readers of scientific writings has been vastly enlarged. Scientific journalism affords an outlet for communications on scientific subjects, which are not necessarily contributions to scientific knowledge. At the same time, this form of publication generates a continued discussion, often followed by republication, of outstanding contributions, which will eventually find their way into scientific literature. As a reservoir of scientific information that can be of significance to the nonspecialist and the lay public, scientific journalism is also linked with journalism in general through the work of professional science writers.

In a positive way, the literature of science can crystallize only after a scholarly criticism of scientific writings has fully emerged. One task of such criticism is to clarify what each form of scientific presentation can contribute to the body of literature as a whole; another, to analyze the intrinsic rules imposed upon the literature by the nature of scientific inquiry in various areas of science. Most important is the scientist's responsibility, in his capacity as critic, to recognize and select from the flow of publications those works that meet the highest standards.

A beginning toward organized criticism in science was made in the annual reviews and review articles. Now scientific book reviews, often discredited in the older disciplines, appear to be gaining. In multidisciplinary areas in particular, book reviews which throw light upon a work from the various interlocking fields can point the way from an indiscriminate mass of scientific writings to scientific literature. When critical judgments are pooled and receive bibliographic recognition over a sustained period, it becomes apparent that such collective criticism tends to sift and to lift out the works that are substantial, articulate, and mature. This process can shorten the time needed for a selection of contemporary scientific 
literature. Just as, in the words of Joseph de Maistre, "Chaque nation est pour l'autre une postérité contemporaine," ${ }^{15}$ so can each related discipline be a discerning critic for another. Once established, criticism in science should find its own form of expression. It can then make scientific literature, as R. A. Scott-James put it for the relation of literary criticism to literature in general, "self-conscious about itself, about its own processes, its technique, its aim."16

In the February 1963 issue of The Rockefeller Institute Review, John Maddox has raised the crucial question: "Is the Literature Worth Keeping?" 17 We believe that what deserves to be called literature in science is worth keeping, but we need not look for it in the machines that may eventually assist us in recording it. A chiefly technological approach has been promoted for about twenty years

\footnotetext{
${ }^{15}$ Louis Paul Betz, Studien zur vergleichenden Literaturgeschichte der neueren Zeit (Frankfurt a. M. : Rütten \& Loening, 1902), p. 13.

${ }^{16} \mathrm{Op}$. cit., p. 14 .

17 "Is the Literature Worth Keeping?" Rockefeller Institute Review, I (1963), 9-14; an abridged version appears in Bulletin of the Atomic Scientists, XIX (November 1963), 14-16.
}

now, and yet the "crisis in scientific information" has been aggravated rather than relieved. Underlying this crisis is the lingering use of a concept of scientific literature which was new at the turn of the century. It was a misunderstanding to apply this concept directly to the bibliography of twentieth-century science by merely trying to list all current publications in a given field.

The time has come to cultivate a concern over the evolving contemporary scientific literature, and to develop adequate bibliographic methods through a scholarly approach. This need not be done in an atmosphere of crisis. By taking the longer view of the historian, the humanist, and the librarian, we can see even now that some problems of scientific information storage and retrieval seem to defy solution because they do not need one. For information that does not contribute to scientific knowledge is not worth retrieving, and the only indestructible way of storing scientific knowledge is by allowing it to become scientific literature, and by helping it to become so recognized and known.

\section{Winchell, Walford, or Malcles?}

(Continued from page 26)

Its index would be thorough and its format similar to that now used by Winchell, if this would be possible under required printing methods.

Wilson's Reader's Guide to Periodical Literature is now available in the regular edition and also in an abridged edition for small libraries. Perhaps a similar arrangement could be developed for a guide to reference sources. This could be on a three-step basis: (1) an "international" edition of broad scope for large public and university libraries; (2) a small edition primarily national in scope, for smaller public libraries; and (3) a middle edition for the medium-sized libraries.

A full-time organization would probably be necessary to handle a production of this scope. However, the gap around existing reference guides widens each year. A practical tool must be developed to fill this gap. 